\title{
ЧАС І ПРОСТІР ЯК ФЕНОМЕНИ ОНТОЛОГІЧНОЇ ПОЕТИКИ УКРАЇНСЬКОЇ НОВЕЛИ КІНЦЯ ХІХ - ПОЧАТКУ ХХ СТОЛІТЬ
}

\author{
Лях Т. 0.
}

\section{ВСТУП}

Кінець XIX - початок XX століть в українському літературному процесі позначений складними мистецько-естетичними пошуками відповідей на філософські питання. Суть цих пошуків полягає в осмисленні ролі індивідуальності людини, ii внутрішнього єства, буття у світі, адже «прикметою доби стає посилення взаємовпливів література - філософія і філософія - література, які виявилися, з одного боку, в інтелектуалізації красного письменства, а 3 іншого в «охудожненні», естетизації філософської думки» ${ }^{1}$.

Зміни світоглядних принципів відбувалися як під впливом західноєвропейської філософії, яка на зламі минулих століть на перший план висуває ірраціональні мотиви людської поведінки, так і завдяки національним традиціям. Гурт митців, які творили у відмінній від старої стильовій манері, І. Франко назвав «новою генерацією»: «<..> виросла тепер найновіша генерація, яка прагне цілком модерним європейським способом зобразити своєрідність життя українського народу. Як найвизначніших представників цієї генерації слід тут назвати Ольгу Кобилянську, Василя Стефаника, Леся Мартовича, Антона Крушельницького, Михайла Яцківа та Марка Черемшину»².

Названі письменники осмислювали у своїх творах ключові онтологічні модуси - страждання, тугу, любов, самотність. За словами Ю. Кузнецова, переживання - «основний об'єкт, який цікавить митців нової школи» ${ }^{3}$. Отже, у поетиці української новели зламу минулих століть домінує «внутрішній монолог, «потік свідомості», асоціативний

1 Криловець А.О. Українська література перших десятиріч XX століття: філософські проблеми. Тернопіль, 2005. С. 12.

${ }^{2}$ Франко I. Українська література. Твори: у 50 т. Т. 33. Київ, 1982. С. 142.

${ }^{3}$ Кузнецов Ю.Б. Імпресіонізм в українській прозі кінця XIX - початку XX ст.: проблеми естетики і поетики. Київ, 1995. С. 116-117. 
монтаж, перетин пам'яті й миттєвого переживання в оповідному часі, тенденція до ускладнення тропіки» ${ }^{4}$.

Саме увага письменників до взаємин людини зі світом у всіх його аспектах - соціальному, національному, природному, осмислення людського буття поетичною мовою - дає підстави розглядати український модернізм у контексті західноєвропейської філософії, вивчати його онтологічну поетику.

Онтологічна поетика - «принцип герменевтики, спрямований на виявлення у художньому тексті, в його сюжетних зв'язках, деталях, мотивах та вчинках персонажів «іншої реальності», на розкриття втілених у метафорико-символічній, сюжетно-образній структурі твору зв'язків особистісного буття автора 3 буттям всесвіту» ${ }^{5}$. У науковий обіг цей термін увів Л. Карасьов. Дослідник відзначає, що термін «онтологічна» виражає «потребу вказати на ті глибинні, буттєві <..> основи, 3 яких текст виростає і певним чином оформлюється», дослідник тлумачить онтологічну поетику як реконструкцію художнього тексту, яка відтворює його глибинні сенси аж до авторського міфу: «онтологічний підхід націлений на визначений i досить специфічний прошарок або рівень оповіді, який радше реконструюється, ніж є присутнім у матерії тексту» ${ }^{6}$.

Якщо онтологічну поетику розглядати у ширшому філософському контексті, то не можна оминути фундаментальні категорії простору і часу, які $є$ базовими для філософської онтології, вони «позначають основні форми буття матерії. Простір передає спосіб співіснування розмаїтих матеріальних утворень, час - спосіб зміни матеріальних явищ» ${ }^{7}$.

Переосмислення онтологічної проблематики в західноєвропейському філософському мисленні припадає на кінець XIX початок XX століть. У цей час у філософії актуальним є буття людини у світі, яке осмислюється крізь призму часових i просторових відношень. Така тенденція стає ключовою в онтологічній філософії різних західноєвропейських мислителів, та чи не найбільш грунтовно буття в контексті часу і простору дослідив М. Гайдеггер. У праці «Буття і час» (1927) філософ із точки зору феноменології

4 Ткаченко А. Стиль. Напрям. Метод. Тип творчості. Слово $і$ час. 1997. № 4. C. 49.

5 Літературознавча енциклопедія: у 2-х т. / авт.-укладач Ю.І. Ковалів. Т. 2. Київ, 2007. C. 154 .

${ }^{6}$ Карасев Л.В. Онтологическая поэтика (краткий очерк). Эстетика: Вчера. Сегодня. Всегда. Вып. 1. Москва : ИФ PAH, 2005. URL: https://iphras.ru/page51136185.htm (дата звернення: 15.12.2020).

${ }^{7}$ Філософський енциклопедичний словник / ред. колегія: В.І. Шинкарук (гол.) та ін. ; Інститут філософії ім. Г.С. Сковороди НАН України. Київ : Абрис, 2002. С. 529. 
і герменевтики розглядає онтологічну структуру людського існування, де ключову роль відіграє «буття-у-світі» людини або «присутність»: «фундаментальну онтологію <..> потрібно шукати в екзистенційній аналітиці присутності» ${ }^{8}$. Саме присутність людини у світі визначає простір, який філософ називає «структурним моментом буття-у-світі». Ще вагомішу роль М. Гайдеггер відводить часові: «лише з укорінення присутності в темпоральність стає очевидною екзистенційна можливість феномена $<\ldots>$ буття-у-світі» ${ }^{9}$.

Щодо художньої літератури, час $\mathrm{i}$ простір тут вважаються підвалинами тексту на рівні змісту і форми, векторами свідомості суб'єкта. Вперше у такому сенсі час і простір у художньому тексті розглянув М. Бахтін, увівши до літературознавчого обігу термін «хронотоп» («часопростір»). На думку вченого, «в літературнохудожньому хронотопі має місце злиття просторових і часових прикмет в осмисленому і конкретному цілому. Час тут густішає, стає щільним і художньо-зримим; простір - інтенсивним, втягується в рух часу, сюжету, історії. Прикмети часу розкриваються у просторі, і простір осмислюється й вимірюється часом» ${ }^{10}$.

Метою цього дослідження $є$ вивчення на прикладі яскравих зразків української новелістики кінця XIX - початку XX століть функціонування часу i простору як онтологічних феноменів художнього твору. Ці філософські категорії визначають буття людини у світі, а тому відображають зміст філософії певного автора, світоглядні тенденції українського модернізму. Філософсько-естетичний підхід до об'єкта дослідження - новелістики кінця XIX - початку XX століть передбачає застосування системного підходу, типологічного, історикокультурного, герменевтичного методів.

\section{1. Час і простір як суб'єктивно-авторське вираження буття}

В онтологічному полі філософії важливу роль відіграє суб'єктивність як ознака людської індивідуальності, а також один із феноменів людського буття - свідомість, що відображає внутрішній сенс взаємин людини зі світом. Суб'єктивізм - основна риса української новели кінця XIX - початку XX століть. Це позначилося на iii поетиці, прикметами якої $\epsilon$ настроєвість, сугестивність, асоціативність, ліризм. В. Шмід називає новелу «найбільш поетичним жанром оповідної прози». Поетичність новели, на думку вченого,

${ }^{8}$ Heidegger M. Being and time / translated by Joan Stambaugh. New York, 1996. P. 11.

${ }^{9}$ Там само, p. 322.

${ }^{10}$ Бахтин М.М. Вопросы литературы и эстетики. Москва, 1975. С. 244. 
позначається на таких художніх прийомах, як «парадигматизація (введення в текст на всіх рівнях, які розрізняються, еквівалентностей, тобто подібностей і протилежностей)»; «тектоніка, геометричність побудови дії і тексту»; «двоїсте (буквальне та переносне) значення усіх слів, перш за все мовних кліше» ${ }^{11}$ тощо.

Повернення митців кінця XIX - початку XX століть "zuruck zur Seele" (О. Кобилянська) сприяло художньому вираженню власної самосвідомості, творенню авторського міфу. Духовне становлення героя відображено в автобіографічних новелах «Карби» (1901) Марка Черемшини, «Моє слово» (1899), «Дорога» (1900), «Давня мелодія» (1926), «Нитка» (1927) В. Стефаника. До речі, останній з названих творів присвячений авторові «Карбів».

Події новели «Карби» відповідають фактам життя письменника. На головного персонажа Марко Черемшина проєктує власні переживання, що на рівні поетики веде до онтологізації часу і простору.

Ліричний заспів новели своїми жанрово-стильовими рисами відповідає жанру поезії в прозі: написаний короткими ритмічними абзацами, він містить символічні образи, наповнені філософським змістом, пройнятий переживанням письменника за рідний край, який на зламі минулих століть перебував у важкому національному та економічному становищі.

Поетику простору цього фрагмента новели автор будує на контрастах: «зелене село» (повнота життя) - «село тихоньке, таке зарошене», «деревище у мокрій ямі межи німими могилами»; «дрібненька запашна отава» - «сухі, надмогильні квітки»; «ожеледдю зажеледять» - «коло серця їх грів би» 12 . Перелічені образи є бінарними і втілюють думку автора про мінливість усього існуючого, про початок («дубова колиска») i кінець («деревище у мокрій ямі»). Власне тут Марко Черемшина торкається міфологічного мотиву вічного відродження, уявлення про яке було у віруваннях майже всіх давніх народів: у античній міфології (міф про Деметру та Персефону) та у християнстві («Усі ріки течуть у море, та море не наповнюється. До місця, звідки течуть ріки, туди вони повертаються знову» ${ }^{13}$ ). Пізніше цю ідею розвинув давньогрецький філософ Геракліт, який постійний хід розвитку порівнював з течією ріки, в яку не можна увійти двічі.

11 Шмид В. Проза как поэзия: Пушкин, Достоевский, Чехов, авангард. СанктПетербург, 1998. С. 3-38.

12 Черемшина Марко. Новели; посвяти Василеві Стефанику; ранні твори; переклади; літературно-критичні виступи; спогади; автобіографія; листи. Київ, 1987. C. 24.

13 Святе Письмо Старого та Нового Завіту. Київ : Українське біблійне товариство, 1992. С. 731. 
Наскрізною є думка письменника, що змінюється матеріальна, тілесна оболонка села (воно то «розкидає чічки», то стає «сухими, надмогильними квітками на цминтарних, струпішілих хрестах»); незмінною залишається духовна субстанція, без якої не існувало б матеріальної, ідея рідної землі, рідного народу. Так автор онтологізує простір новели, підносить локацію рідного краю, села до рівня невід'ємної частини буття людини. Село як місце рідних авторові людей, їхніх страждань і доль здатне залишити карби на серці ліричного героя: «Лиш варуйте серце, бо воно (село. - Т.Л.) вам серце покервавить, глибоко покарбує» ${ }^{14}$.

Якщо в ліричному заспіві наявність «я-оповідача» окреслює внутрішній сюжет, розвиток переживання ліричного героя, то у другій частині використано гетеродієгетичну форму нарації, що вже відображає зовнішній сюжет твору, а мотив карбування набуває додаткових конотацій.

О. Червінська пропонує вивести символ «<..> за межі формальних тлумачень тропа в площину онтології свідомості, вважаючи в цьому сенсі, що символ першочергово містить у собі потужний елемент, що активізує реципієнта, свідомість якого повинна завершити його формування» ${ }^{15}$. Саме в аспекті онтології свідомості слід розглядати символ карбів. Карби людські гріхи на палиці у Бога. Уже ця первісна семантика символу промовляє до свідомості читача, адже концепт гріха $є$ невід'ємним атрибутом буття кожної людини. У свідомості героя з карбами асоціюються людські кривди. Семантика карбів переходить в онтологічний вимір: через карби Петрик пізнає трагізм людського буття.

Карби - не лише ідейний і композиційний центр твору. Із ним пов'язані категорії часу і простору новели. У міру збільшення карбів на серці Петрика розширюється місце дії (хата батька, діда, ціле село) та час, що охоплює події від дитячих років героя до його юності, коли формуються світоглядні принципи. Події дитинства та юності Петрика (перебування в діда, слухання змалку народних пісень та казок, від’їзд на навчання в місто, смерть бабусі) утворюють не лише зовнішній, а i внутрішній сюжет, авторський міф, тому що акумулюють у душі героя певні переживання та емоції, безпосередньо впливають на формування його життєвої позиції.

Ще одним феноменом простору в новелі $є$ архетип дому, який відіграє знакову роль у формуванні ментальності людини. У дідовій хаті відбувається одночасне поєднання трьох часових площин -

\footnotetext{
${ }^{14}$ Черемшина Марко. Новели... С. 24.

15 Червинская О. Рецептивный ресурс символа. Symbol w paradygmatach kultury europejskiej. Vol. II. Siedlce, 2010. S. 13.
} 
минулого, теперішнього і майбутнього, що втілюють три покоління одного Роду. Архетип дому втілює ідею єдності людини зі своїм корінням, а також міфологічну ідею вічного колообігу і повернення, втілену в біологічному продовженні життя у своїх нащадках та духовному - в пам'яті прийдешніх поколінь.

Пам'ять i розповіді діда про героїчне минуле свого народу («Показував пальцями мальованих стрільців на комині та й розказував, як вони татарів та багачів різали, смолою обкапували» ${ }^{16}$ ) формують у новелі категорію часу, творять спільний міф, що, за Е. Смітом, актуалізує національну ідентичність ${ }^{17}$.

Актуалізація прачасу в новелі розкриває буття персонажів в історичному вимірі. У розповідях діда виявляється одна з головних бінарних опозицій міфологічної моделі світу: «добро - зло», яку втілювали «стрільці» (добро), що боролися з ворогами (зло). Петрик сприймає дійсність відповідно до міфічного протистояння добра і зла. Горе і кривду (зло) в дитячій уяві втілюють карби - «темні вороги», яких можна легко, мов у казці, знищити («<..> єк купите мені стрільбу, то я тоті карби вистрілєю шо до лаби!» $\left.{ }^{18}\right)$. У дорослому віці міфологічна модель боротьби добра зі злом вплине на формування життєвого кредо героя.

Переломною подією в житті героя стає бабусина смерть, тоді Петрик дізнається, що «перед смертев кождому карби показуютси, на душу чікают. <...> Шо гріх, то все карб на палици у пана Бога та й на души карб. Єк душя на тот світ приходит, то єї карби уже пораховані, уже муки терпіти має» ${ }^{19}$. Отже, карби в цьому фрагменті новели, за спостереженням М. Голянич, «експлікують своєрідність семантичних зв'язків між концептами знак - гріх - страждання, смерть - Бог - доля». Така концептуальна структура новели, на думку дослідниці, виявляє «засаду історичного виміру буття, <..> взаємозв'язок поколінь, здатність відплачувати за щось, наприклад, за карби - принесені комусь страждання, здатність відмолювати гріхи за предків, знявши з них знак i тягар карбів» ${ }^{20}$. Цей обов'язок належить Петрику, він - бабин

\footnotetext{
${ }^{16}$ Черемшина Марко. Новели... С. 25.

${ }^{17}$ Сміт Ентоні Д. Національна ідентичність/ пер. 3 англ. П. Таращук. Київ, 1994.

${ }^{18}$ Черемшина Марко. Новели... С. 27.

${ }^{19}$ Там само. С. 30.

${ }^{20}$ Голянич М. Інтертекстуальний характер внутрішньої форми ключового слова (на матеріалі художніх текстів Марка Черемшини). «Покутська трійия» в загальноукраїнському літературному прочесі кіния XIX - початку XX століття : зб. наук. праць / упоряд. С. Хороб. Івано-Франківськ, 2006. С. 281.
} C. 23. 
«одинокий рятівник». Саме зараз герой усвідомив, що карби на його серці «ніколи не загояться і не заростуть панським салом».

Як і Петрик із «Карбів», герой «Давньої мелодії» В. Стефаника в дитинстві уважно слухає давню колядку. Коляда тут стає концептуальним образом, у якому перетинаються різні часові площини: героїчне минуле України, яке відображають відважні лицарі в коляді, i сучасне, адже про них маленькому Василькові співають у часові теперішньому (в новелі Марка Черемшини таку функцію виконує образ мальованих стрільців). Отже, Василько «твердо постановив ніколи свого коня не продати», бо ж «рефрен української історії мужньо звучав у того коня» ${ }^{21}$.

Простір визначає буття ліричного героя В. Стефаника в «Моєму слові». Автор малює свій «хід» по життю, що поділене навпіл: до перебування в місті та після. До - він був щасливим, «у біленькій сорочці, сам білий». Коли покинув рідний йому світ, потрапив у «новий світ, новий і чорний». Відтоді ліричний герой - «листочок білої берези на сміттю», «жебрак маленький», що «занімів був із болю» ${ }^{22}$. Ця опозиція двох полярних («чорного» та «білого») світів згодом на все життя міцно укоріниться у свідомості митця: «Праворуч мене синє поле, i чорні скиби, і білий плуг, і пісня, і піт солений. / Ліворуч чорна машина, що 3 червоного рота прокльоном стогне» ${ }^{23}$.

Зміна простору у творі передбачає повернення до того, що становить духовну основу буття, марковану в тексті білим кольором, який також $є$ кольором Абсолюту. Просторові координати новели переломлюються крізь призму свідомості автора i переходять у метафізичну площину.

Постійна роздвоєність світобудови ліричного героя «Мого слова» створює психологічний дискомфорт, порятунок від якого автор знаходить у творчості. Він вирішуе «створити собі свій світ»: «А в серці моїм мій світ шовком тканий, сріблом білим мережаний i перлами обкинений».

«Буду свій світ різьбити, як камінь. <..> А свій камінь буду різьбити все, все! ${ }^{24}$, - проголошує В. Стефаник. Марко Черемшина також різьбить свій світ, карбує своє серце. Щоправда, образ каменю у нього завуальований. На нього натякає семантика імені головного героя новели (Петро в перекладі $з$ грецької означає «скеля, камінь»), що відповідає ідейно-композиційному рівню новели, структуру якої

${ }^{21}$ Стефаник В. Вибране. Ужгород, 1979. С. 192.

22 Там само. С. 156.

${ }^{23}$ Там само. С. 157.

${ }^{24}$ Там само. 
визначає образ карбів, карбування як відображення людського буття, бо ж карбувати - різьбити по дереву чи каменю.

Новелу «Дорога» В. Стефаника типологічно зближує з новелою Марка Черемшини «Карби» образ життєвого шляху, духовного становлення героя. Дорога тут становить онтологічну єдність часу і простору, символізує долю людини. Ліричний герой В. Стефаника «пішов, бо стелилася перед його очима ясна і далека (дорога - T.Л.)». Він зустрічав на своїй дорозі людей, що були «страшними лицями обернені до неба, як морем голов проти моря звізд», і від цього дорога «як полотно, під ним угиналася» ${ }^{25}$. Життєвий шлях автогероя Марка Черемшини також устелений кривдами, що стали карбами на його серці. Онтологічну єдність часу і простору, що разом становлять долю людини, символізує образ нитки в однойменній новелі В. Стефаника: «Нитка довга та предовга без кінця, ніхто не скінчив нитки», «свою нитку я доведу до кінця» ${ }^{26}$.

Суб'єктно-авторське вираження буття через просторові координати наявне у новелі М. Коцюбинського "Intermezzo" (1908). Простір тут формує ліричний сюжет твору, з одного боку, а з іншого - відображає філософське осмислення автором метафізики мистецтва, сенсу творчості, власного буття.

Втома від світу й людей спонукає ліричного героя "Intermezzo" здійснити вихід за межі звичних реалій (культури, соціуму) і відчути бажану свободу. Зміна звичного простору міста на природу («кононівські поля») відображає метафізичний мотив повернення людини до духовних першооснов світу.

Опозиція природи і міста в Коцюбинського дає підстави розглядати просторові координати новели в онтологічному аспекті і корелює 3 протиставленням М. Гайдеггера «Відкритого як цілокупности сущого, «непредметного» світу природи i «предметного» світу» ${ }^{27}$. «Предметність» світу філософ розуміє як зведення його людиною до об’єкта, яким треба розпоряджатися: «Людина ставить світ як предметність у цілому наперед себе і себе перед світом. Людина чинить так, що світ наставляється на неї, а природа приставляється до неї» ${ }^{28}$. Цим самим людина ігнорує шлях до Відкритого: «Невиразні утвори технічної продукції громадяться перед Відкритим чистого стосунку. Зрослі колись речі зникають у тому ж напрямку. Йдучи і переходячи

${ }^{25}$ Там само. С. $99-100$

${ }^{26}$ Там само. С. 191.

27 Гайдеггер М. Навіщо поети? Слово. Знак. Дискурс: антологія світової літературно-критичної думки ХХ сm. / за ред. Марії Зубрицької. Львів, 2001. С. 235.

${ }^{28}$ там само. С. 236. 
через упредметнювання, вони вже не можуть показати того, що їм властиве» ${ }^{29}$.

Проблема втрати людиною своїх духовних первнів через «опредмечування» світу відображена у внутрішньому опорі ліричного героя "Intermezzo" Людині: «Се ти одягла землю в камінь й залізо, се ти через вікна будинків - тисячі чорних ротів - вічно дихаєш смородом. Ти бичуєш святу тишу землі скреготом фабрик, громом коліс, брудниш повітря пилом та димом, ревеш від болю, з радості, злості» ${ }^{30}$.

Ще однією локацією, куди потрапляє ліричний герой, стають кімнати як «опредмечений» простір. «Десять чорних кімнат», які «облягають мою кімнату», страх, що «світло лампи витече все крізь шпари», а також почуття, того, що щось «поза своєю стіною < ..> мені заважає»є місткою метафорою свідомого і несвідомого митця. «Моя кімната», залита світлом лампи, втілює Самість героя, намагання осягнути світ метафізично, тобто не очима, а зором внутрішнім: «що робиться там, де людина не може бачити...» ${ }^{31}$, натомість образ «чорних кімнат» проєктує несвідому сторону психіки (за Юнгом, Тінь).

На лоні природи митець, як i ліричний герой В. Стефаника в «Моєму слові», утверджує буття свого світу: «Я тепер маю окремий світ, він наче перлова скойка: стулились краями дві половини - одна зелена, друга блакитна - й замкнули у собі сонце, немов перлину. А я там ходжу і шукаю спокою» ${ }^{32}$.

Метафізичний горизонт буття, творчого мислення автора оприявнює в новелі відкритий простір. Природа, за Гайдеггером, «є основою того сущого, котрим є й ми самі, його праосновою» ${ }^{33}$. Природа спонукає Коцюбинського до творення, а значить до пізнання істини, яка «тотожна сутності мистецтва. Вона не є результатом нашого судження, вона не в нас, а у творі» ${ }^{34}$.

Поєднання бінарних просторових векторів - землі й неба відображає сенс буття, що для митця полягає у творчості: «Сіра маленька пташка, як грудка землі, низько висіла над полем. Тріпала крильми на місці напружено, часто і важко тягнула вгору невидиму струну від землі аж до неба» ${ }^{35}$.

Таке розуміння творчості Коцюбинським нагадує «суперечку землі і світу» М. Гайдеггера, у якій мислитель утілив свою концепцію істини в мистецтві. Концепту неба Коцюбинського (як сфери духовного) відповідає поняття світу Гайдеґгера: «Світ не буває предметом - він

${ }^{29}$ Там само. С. 238.

${ }^{30}$ Коцюбинський М. Твори: у 7 т. Т. 2. Київ, 1974. С. 297.

31 Там само. С. 299.

32 Там само. С. 302.

${ }^{33}$ Гайдеггер М. Навіщо поети? С. 233.

${ }^{34}$ Фізер І. Філософія літератури. Київ, 2012. С. 37.

${ }^{35}$ Коцюбинський М. Твори: у 7 т. Т. 2. Київ, 1974. С. 307. 
$\epsilon$ та непредметність, якій ми підпорядковані, допоки кругообіг народження і смерті, благословення і прокляття штовхають нас углиб буття» ${ }^{36}$; «відновлювання, воздвигнення світу і упорядкування землі суть дві сутнісні риси буття творення творінням. У єдності творчого буття вони належать одна одній і взаємопов'язані. I цю сукупну їх єдність ми прагнемо відшукати $<\ldots>{ }^{37}$. Отже, із «суперечки землі і світу» постає «буття творення», первісна основа мистецтва, а отже, відбувається утвердження істини через творення. У взаємодії протилежного - земного і небесного, духовного і тілесного - бачив сенс творчості М. Коцюбинський, що відображає феномен простору новели "Intermezzo".

\section{2. Часопросторові координати діонісійського буття в українській новелі кінця XIX - початку XX століть}

Оновленню української літератури сприяло осмислення філософії $\Phi$. Ніцше, зокрема його концепції аполонівського і діонісійського первнів людського буття, де аполонівське втілює раціоналізм, гармонію, пропорцію, стриманість, діонісійське - ірраціоналізм, спонтанність, тілесність, екстатичне самозабуття. За Ф. Ніцше, в бутті людини, як і в мистецтві, аполонівське та діонісійське повинні гармонійно поєднуватися: «обидва ці мистецькі гони змушені розгортати свої сили у сильній взаємній пропорції, згідно із законом вічної справедливости» ${ }^{38}$.

Серед українських новелістів зламу минулих століть уплив Ніцше чи не найбільше позначився на творчості О. Кобилянської та Марка Черемшини. У творах Марка Черемшини переважає сфера первісного буття, за Ніцше, діонісійське начало. Розуміння автором сенсу людського буття суголосне ніцшеанській філософії життя. У творах О. Кобилянської спостерігаємо протистояння аполонівського діонісійському.

Філософія вітаїзму $є$ основним ідейним стрижнем новел О. Кобилянської «Природа» (1887) та Марка Черемшини «Зарікайся мід-горівку пити!» (1923). Сюжет творів становить кохання між чоловіком і жінкою на тлі природи, яка суголосна почуттям героїв, що виводить простір в онтологічну площину.

Новела «Зарікайся мід-горівку пити!» складається 3 двох частин: смерть чоловіка головної героїні, іiї туга за ним та зародження нового

${ }^{36}$ Хайдеггер М. Исток художественного творения. Зарубежная эстетика $u$ теория литературы XIX-XX вв.: трактаты, статьи, эссе / сост., общ. ред. Г.К. Косикова. Москва, 1987. С. 284.

${ }^{37}$ Там само. С. 287.

38 Ніцше Ф. Народження трагедії з духу музики (Фрагменти). Слово. Знак. Дискурс: антологія світової літературно-критичної думки XX $\mathrm{cm}$. / за ред. М. Зубрицької. Львів, 2001. С. 69. 
кохання. Простір у творі відображає два аспекти буття людини: життя i смерть. Похорон чоловіка Килини відбувається в замкненому просторі - в хаті, яка в такому разі стає наче другою домовиною для невтішної вдови, котра «так голосила на похороні свого газди, що селу серце тріскало./ I приповідала, і заводила, і заклиналася. Не то що плакала, а розливом розливалася, як біла мрака травами». Натомість ідилічну картину зустрічі Килини та Івана автор малює на лоні природи, коли «на Юра пукла над ріками лоза, а лісами закувала зозуля»». Саме тоді душа «вічної удовиці» Калини оживає, в ній знову зароджується кохання.

Простір у творі відіграє ще й психологічну функцію. Письменник проводить паралель між піднесеним душевним настроєм закоханих і природою навесні: «А зазуля кує, ні - аж гай розвивається.

А річка срібним поясом тот гай то вперізує, то розперізує.

А Калинина маржина гейби до півусміху роти відтворила і надслухує, то зазирає та й помалу-помалу ступ-ступ 3 полонинки на Йванову

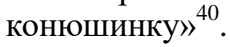

Взаємопроникнення зовнішнього i внутрішнього світів Марко Черемшина відтворює крізь призму пантеїстичного світовідчування, де «чоловік, як мікрокосм, розпускається в частині натури» ${ }^{41}$. Зорові та звукові образи весняного пейзажу творять радісний настрій, який також увиразнює ритмізація мови. Автор використовує короткі абзаци 3 однорідними синтаксичними одиницями переважно народнопісенного характеру: «Палають цвіти попід лісами, над берегами, над вулицями, над керницями.

Розщебеталася німа діброва, порозліталася медова бджілка, порозлягалися запашні вітри.

Про то весна яра...» ${ }^{42}$.

Цей фрагмент новели можна виділити в окремий самостійний твір, що нагадує поезію в прозі, пейзажну мініатюру 3 філософським підтекстом. Марко Черемшина відтворює найпрекраснішу пору року весну, іiі буйне цвітіння, апофеоз життя і любові. Такою ідейносмисловою настановою ця частина новели перегукується з поезією у прозі «Весна» (1895) I. Шлафа, твори котрого стали об'єктом перекладацької творчості Марка Черемшини. У своїй імпресіоністичній мініатюрі німецький письменник малює радісний образ весни. За твердженням Л. Андрєєва, у Шлафа «сильна концентрація емоційносуб'єктивного начала перевтілює «душу» в «дух», а з-під наглядної, непоказної, як видається, зовнішності весняної природи виглядає Сила.

${ }^{39}$ Черемшина Марко. Новели... С. 217.

40 Там само. С. 217-218.

41 Нечуй-Левицький I. Світогляд українського народу: ескіз української міфології. Київ, 1992. С. 67.

42 Черемшина Марко. Новели... С. 218. 
Образи набувають символічного значення, натякають на приховане i загадкове єство» ${ }^{43}$. Як i в німецького письменника, у Марка Черемшини кожна деталь весняного пейзажу символічна, а в кінці уривку з'являється найпотужніша «Сила» - Бог: «А Господь понад гори походжає і сонечком дихає на ввесь світ, на гори й долини та й на полонини./ Та й на Калинину любість золотом мече» ${ }^{44}$.

Так, через просторові і часові координати Марко Черемшина втілює в новелі свою філософію життя: людина - центр Космосу, частина усього живого світу, сотвореного Богом. Всевишній дарує їй, як і кожній живій істоті на світі, на яку «дихає сонечком», свій найцінніший дар - любов. У автора любов - цінніша коштовного золота, адже ії Бог «золотом мече», сильніша смерті, бо через почуття любові людина навіки зливається з природою і радіє так, як «радується на ріллі скиба, у ріці риба, царинками зело», тобто сповнюється благодаттю Божою, у якій і є сенс буття. Таке метафізичне розуміння Марком Черемшиною любові суголосне 3 думками Е. Фромма про те, що людина, відчуваючи любов до іншої людини, «любить усе людство, все, що $\epsilon$ живе» ${ }^{45}$. Поняття любові в новеліста пов'язане 3 відчуттям гармонії не лише між двома закоханими, а й 3 усім світом. Завершальним акордом новели стає коломийка, що підкреслює ідею твору, філософію гуцулів трактувати любов як невід'ємну частину людського буття: «Зарікайся, файна любко, мід-горівку пити, / Та лишень ся не зарікай Івана любити» ${ }^{46}$.

Кохання на лоні чудової краси Карпатських гір відтворює О. Кобилянська у новелі «Природа» (1887), де внутрішній конфлікт можна розглядати як протистояння аполонівського і діонісійського. За слушним спостереженням Т. Гундорової, гуцул перебуває «у сфері впливу Діоніса, вегетації чуття», натомість дівчина «виходить поза сферу чистої природи, базованої на діонісійстві, і вступає у сферу аполонівського самоконструювання, себто у сферу культури» ${ }^{47}$.

Простір у Кобилянської визначає єство людини, втілює несвідомі потяги юнака i дівчини. Прикметно, що зближення між ними відбувається в лісі, який у психоаналізі часто асоціюється 3 несвідомим: «I вони йшли далі в ліс, де ставало все тихіше та тихіше; хіба що крізь ту тишу продирався голос джурчачого потоку» ${ }^{48}$.

43 Андреев Л.Г. Импрессионизм. Москва, 1980. С. 157.

${ }^{44}$ Черемшина Марко. Новели... С. 218.

45 Фромм Э. Искусство любви: исследование природы любви / пер. с англ.

Л.А. Чернышевой. Минск, 1991. С. 34.

${ }^{46}$ Черемшина Марко. Новели... С. 218.

${ }^{47}$ Гундорова Т. Femina Melancholica: стать і культура в гендерній утопії Ольги Кобилянської. Київ, 2002. С. 41.

${ }^{48}$ Кобилянська О. Твори: у 3 т. Т. 1. Київ, 1956. С. 387. 
Як і в новелі Марка Черемшини, пейзаж тут виконує смислову функцію: «Осліпляюче і немов упоєне побідою заблисло сонце на заході пишним золотом, й ніжно-ясні облаки навколо нього перемінилися в яркий червоний жар» ${ }^{49}$. Золотий колір автори насичують позитивною семантикою повноти людського буття. В новелі Марка Черемшини почуття персонажів зароджуються на «полонинці», тобто на рівнині. О. Кобилянська «веде» своїх героїв на гору, в чому прочитується ніцшеанський мотив істини, творчої волі, а разом із тим образ нової людини: «Вдруге народитися закликав нас Ніцше, і гори підніжжя новонародженого» ${ }^{50}$.

У Марка Черемшини час (весна) і простір (природа) є невід'ємною частиною буття персонажів, хронотопом їхнього кохання, духовного єднання людини зі світом. Слушною для черемшинівського розуміння любові видається думка В. Моренця про те, що ерос як філософський концепт «значно ближчий до християнської ідеї Любові, ніж тілесного кохання» ${ }^{51}$, натомість О. Кобилянська у «Природі» акцентує на «тілесному» аспекті кохання.

У новелі «Природа» авторка малює «роман на мент», палку пристрасть між чоловіком та жінкою, що так і не стала справжнім коханням. На запитання гуцула «Любиш мене?» дівчина дала заперечну відповідь, пояснюючи: «бо то щось інше» ${ }^{52}$. Юнак переборює в собі почуття пристрасті до панни, вважаючи, що вона відьма i причарувала його: «Йому мусило усе те статися, бо спровадився до своєї нової хати вверху, не посвятивши ії перше!» ${ }^{53}$.

Авторка зумисне не наділяє своїх героїв іменами, надаючи їм символічного звучання. Образи дівчини та гуцула втілюють фемінне та маскулінне, мов елементи інь та янь. Письменниця розглядає буття людини як структуру бінарних концептів життя - смерті, свідомого несвідомого, добра - зла. Так, гуцул бачить у дівчині то відьму, то Матір Божу, переживає сильну внутрішню боротьбу, в якій йому вдається побороти свою пристрасть, перемогти сп'яніння діонісійського: «Іде домів, і такий тверезий, такий, «як був перше», що мало не сміється» ${ }^{54}$.

Панна також перебуває у стані душевної роздвоєності між спокоєм і життям, еросом і танатосом («Іноді опановувала іiі невиразна жадоба чувства побіди; але <..> ніколи не заохочувана і не скріплювана,

${ }^{49}$ Там само. С. 388.

${ }^{50}$ Белый А. Символизм как миропонимание. Москва, 1994. С. 181.

51 Моренець В. Національні шляхи поетичного модерну першої половини ХХ ст.: Україна і Польща. Київ, 2002. С. 62.

${ }^{52}$ Кобилянська О. Твори: у 3 т. Т. 1. Київ, 1956. С. 390.

${ }^{53}$ Там само. С. 396.

54 Там само. С. 395. 
розпещена, виніжена, іiі сила спала й ниділа і переходила в хворобливу безпричинну тугу» ${ }^{55}$ ).

Час у творі трактується як вічність, на що вказують художні деталі в тексті, а також портрет героїні, що нагадує Леонардову Мону Лізу: «її очі, великі, трохи нерухомі і вогкі, були сумні і тоді, коли уста усміхалися. За сі очі звали іiі «руською мадонною», «бліді, перстенцями прикрашені руки лежали обімлілі», «червоно-русяві грубі коси, на кінцях розплетені, спадали їй із плечей». Образ Мони Лізи у період Fin de Siècle «перетворюється на інкарнацію magna mater», у ньому прирівнюється «жіноче до безначального, наскрізного, надчасового. Вічно жіноче є воднораз і вічно тривалим, фігурою перед- і постісторії, тим, що їй передувало, і тим, що відбудеться після неї» ${ }^{56}$. На понадчасовість натякає ще одна деталь - годинник героїні.

Перефразовуючи Д. Донцов зазначав про черемшинівський ерос, що його сила «мимо непорадности й наївности одиниць, зберігала расу,

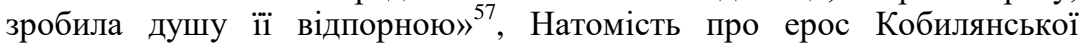
можемо сказати, що його зберігає «раса». Авторка підкреслює, що була iii героїня «русинкою з голови до ніг», «ії бабка по батькові власне була гуцулка». Саме тому дівчина відчула з юнаком духовну спорідненість. У момент їхнього знайомства гуцул зрадів: «Ти так красно говориш понашому». Та коли він починає розшукувати дівчину, його спиняє несвідомий страх, що кохана не належить до його «раси», а отже, ніколи не зможе поєднатися з ним духовно. На це вказує образ матері дівчини, що зринув у спогадах гуцула: «То не може бути ії мати... Вона говорить по-руськи, тим часом як іiі мати говорила бог знає якою страшною мовою» $^{58}$. Тому юнак долає в собі діонісійське, що символічно втілює епізод рубання ним смереки, адже дерево здавна символізує життя і продовження роду.

\section{ВИСНОВКИ}

Українські письменники кінця XIX - початку XX століть переосмислюють взаємини людини зі світом у всіх можливих його аспектах - соціальному, національному, природному. Буття людини у світі, зміст філософії того чи іншого автора відображають у художньому творі категорії часу i простору, що дає підстави розглядати їх як онтологічні феномени української новели зламу минулих століть.

${ }^{55}$ Там само. С. 382.

56 Ассман А. Простори спогаду. Форми та трансформації культурної пам'яті / пер. 3 нім. К. Дмитренко та ін. Київ, 2012. С. 246.

57 Донцов Д. Марко Черемшина. Літературна есеїстика / відп. ред. і упоряд. Олег Баган. Дрогобич, 2009. С. 202.

${ }^{58}$ Кобилянська О. Твори: у 3 т. Т. 1. Київ, 1956. С. 383. 
Суб'єктно-авторське вираження буття спостерігаємо в автобіографічних новелах «Карби» (1901) Марка Черемшини, «Моє слово» (1899), «Дорога» (1900), «Давня мелодія» (1926), «Нитка» (1927) В. Стефаника, М. Коцюбинського "Intermezzo" (1908). У названих творах на першому місці переживання ліричного героя. На рівні поетики це веде до онтологізації часу і простору, які у новелах часто закодовані у символічних образах, містких деталях. Простір і час формують зовнішній сюжет твору, а також відображають філософське бачення автором людини у світі, сенсу творчості.

У новелах О. Кобилянської «Природа» (1887) та Марка Черемшини «Зарікайся мід-горівку пити!» (1923) буття людини осмислюється крізь призму ніцшеанської концепції діонісійського та аполонівського первнів буття. У новелі Марка Черемшини категорії часу і простору переходять в онтологічну площину, природа навесні стає невід'ємною частиною життя персонажів, колискою їхньої любові, яку автор трактує як почуття гармонії людини зі світом. О. Кобилянська розширила семантику природи, що, крім простору, в якому перебувають персонажі, втілює їх несвідоме, відображає протиставлення духовного і тілесного, аполонівського і діонісійського.

Вивчення функціонування часу $\mathrm{i}$ простору як онтологічних феноменів української новелістики кінця XIX - початку XX століть $€$ перспективним, позаяк сприяє розумінню художньої картини світу в iii глибинному сенсі, стає ключем не лише до сприйняття художнього твору, а й філософського дискурсу українського модернізму. Дослідження окреслює аспекти вивчення української літератури у зв'язку з філософією.

\section{АНОТАЦІЯ}

У статті досліджуються час і простір як феномени онтологічної поетики новел Марка Черемшини, Василя Стефаника, Ольги Кобилянської, Михайла Коцюбинського. Досліджено феномени часу і простору, образи-символи, художні деталі в їхньому відношенні до природи людського буття в індивідуальному сприйнятті письменників. 3'ясовано характерні ознаки літературного процесу кінця XIX початку XX століть, які позначилися на творчості авторів. Крізь призму часу i простору розглянуто рецепцію українськими письменниками філософії Ніцше, буття людини та його сенс. Дослідження вказаних онтологічних феноменів також взаємопов'язане з проблемою природи і любові. Зроблено висновок про розуміння авторами аполонівського і діонісійського в людському бутті крізь осмислення часу і простору. Ця розвідка розгортає подальші аспекти вивчення української літератури в контексті міждисциплінарних досліджень. 


\section{ЛІТЕРАТУРА}

1. Андреев Л.Г. Импрессионизм. Москва, 1980. 250 с.

2. Ассман А. Простори спогаду. Форми та трансформації культурної пам'яті / пер. з нім. К. Дмитренко та ін. Київ, 2012. 440 с.

3. Бахтин М.М. Вопросы литературы и эстетики. Москва, 1975. 504 с.

4. Белый А. Символизм как миропонимание. Москва, 1994. 528 с.

5. Heidegger M. Being and time / translated by Joan Stambaugh. New York, 1996. $488 \mathrm{p}$.

6. Гайдеггер М. Навіщо поети? Слово. Знак. Дискурс: антологія світової літературно-критичної думки $X X \mathrm{~cm}$. / за ред. Марії Зубрицької. Львів, 2001. С. 230-249.

7. Голянич М. Інтертекстуальний характер внутрішньої форми ключового слова (на матеріалі художніх текстів Марка Черемшини). «Покутська трійия» в загальноукраӥнському літературному прочесі кіния XIX - початку XX століття : зб. наук. праць / упоряд. С. Хороб. Івано-Франківськ, 2006. С. 275-288.

8. Гундорова T. Femina Melancholica: стать і культура в гендерній утопії Ольги Кобилянської. Київ, 2002. 272 с.

9. Донцов Д. Марко Черемшина. Літературна есеїстика / відп. ред. і упоряд. Олег Баган. Дрогобич, 2009. С. 190-208.

10. Карасев Л.В. Онтологическая поэтика (краткий очерк). Эстетика: Вчера. Сегодня. Всегда. Вып. 1. Москва : ИФ РАН, 2005. URL: https://iphras.ru/page51136185.htm (дата звернення: 15.12.2020).

11. Кобилянська О. Твори: у 3 т. Т. 1. Київ, 1956. 592 с.

12. Коцюбинський М. Твори: у 7 т. Т. 2. Київ, 1974. 384 с.

13. Криловець А.О. Українська література перших десятиріч XX століття: філософські проблеми. Тернопіль, 2005. 256 с.

14. Кузнецов Ю.Б. Імпресіонізм в українській прозі кінця XIX початку XX ст.: проблеми естетики і поетики. Київ, 1995. 304 с.

15. Літературознавча енциклопедія: у 2 т. / авт.-укладач Ю.І. Ковалів. Т. 2. Київ, 2007. 624 с.

16. Моренець В. Національні шляхи поетичного модерну першої половини XX ст.: Україна і Польща. Київ, 2002. 327 с.

17. Нечуй-Левицький I. Світогляд українського народу: ескіз української міфології. Київ, 1992. 88 с.

18. Ніцше Ф. Народження трагедії 3 духу музики (Фрагменти). Слово. Знак. Дискурс: антологія світової літературно-критичної думки ХX сm. / за ред. М. Зубрицької. Львів, 2001. С. 55-70.

19. Святе Письмо Старого та Нового Завіту. Київ : Українське біблійне товариство, 1992. 1397 с.

20. Сміт Ентоні Д. Національна ідентичність / пер. 3 англ. П. Таращук. Київ, 1994. 224 с.

21. Стефаник В. Вибране. Ужгород, 1979. 392 с. 
22. Ткаченко А. Стиль. Напрям. Метод. Тип творчості. Слово $i$ час. 1997. № 4. C. 41-49.

23. Фізер І. Філософія літератури. Київ, 2012. 217 с.

24. Філософський енциклопедичний словник / ред. колегія: B.I. Шинкарук (гол.) та ін. ; Інститут філософії ім. Г.С. Сковороди НАН України. Київ : Абрис, 2002. 744 с.

25. Франко І. Українська література. Твори: у 50 т. Т. 33. Київ, 1982. C. $142-143$.

26. Фромм Э. Искусство любви: исследование природы любви / пер. с англ. Л.А. Чернышевой. Минск, 1991. 80 с.

27. Хайдеггер М. Исток художественного творения. Зарубежная эстетика и теория литературы XIX-XX вв.: трактаты, статьи, эссе / сост., общ. ред. Г.К. Косикова. Москва, 1987. С. 264-312.

28. Черемшина Марко. Новели; посвяти Василеві Стефанику; ранні твори; переклади; літературно-критичні виступи; спогади; автобіографія; листи / вступ. ст., упорядкув. й прим. О.В. Мишанича ; ред. тому В.М. Русанівський. Київ, 1987. 448 с.

29. Червинская О. Рецептивный ресурс символа. Symbol w paradygmatach kultury europejskiej. Vol. II. Siedlce, 2010. S. 11-14.

30. Шмид В. Проза как поэзия: Пушкин, Достоевский, Чехов, авангард. Санкт-Петербург, 1998. 352 с.

\section{Information about the author:} Liakh T. O.,

Candidate of Philological Sciences, Associate Professor at the Department of Public Health and Humanitarian Disciplines of the Medical Faculty No. 2

Uzhhorod National University 46, Pidhirna str., Uzhhorod, 88000, Ukraine 